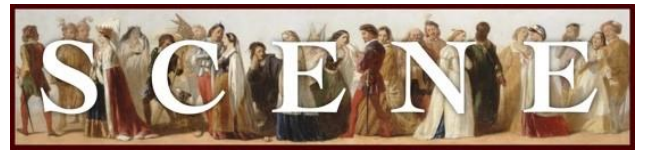

\title{
A Midsummer Night's Dream at the Stratford Festival
}

by Roderick H. McKeown and Sarah Star. Written on 2016-04-25. Published in 2017 Issue 1.

For the production: A Midsummer Night's Dream (2014, Stratford Festival of Canada, Canada). See production details at the end of the review.

In STRATFord's 2014 STAging of A Midsummer Night'S DREAM, DiRECTOR Christopher Abraham's stated intent to "forge a sense of family and community as central to the play's setting, and for this community to be inclusive, varied and diverse" is apparent from the outset, shaping an unusually conceptually sophisticated production. This ranges from minor touches, like making Egeus (Michael Spencer-Davis) deaf, speaking in sign through an interpreter, to the overarching framing conceit: this Dream is a wedding entertainment mounted after a backyard wedding ceremony. The players are a troupe of actors, celebrating the marriage of two actors in the company - and that's not a gender-neutral noun, as we mean two male actors. Abraham's production is lent emotional immediacy by the coincidental recent rulings in a number of American jurisdictions striking down bans on same-sex unions; those rulings were not in the headlines when rehearsals began. The play within the play draws upon the currency of love not legally sanctioned.

The Festival Theatre was decorated throughout as for a wedding, with white bows on the end of every row of seats. The cast mingled freely with the audience, some of whom were actually led to believe that they were attending a special, celebratory performance. The actors ad-libbed freely, asking patrons how far they had come for the ceremony, and whose side of the aisle they were on, and offering tissues. When we jokingly, knowingly, stated we were with the groom, we were corrected, and informed there were two grooms. The "newlyweds" were then led in blindfolded, prefiguring the confusions in the forest.

The most prominent directorial decision that follows on from this frame is the cross-casting of both Lysander (Tara Rosling) and Titania. Casting Hermia and Lysander as two women pleading for their love to be recognized translates Shakespeare's slightly improbable legal scenario into a modern idiom. Many of Lysander's lines - telling Demetrius "Do you marry him" - take on wonderfully ironic meaning. Conversely, Hermia's contempt for "all the vows that ever men have broke" becomes a celebration of lesbian constancy. The patriarchal dynamic that 
underwrites Demetrius' claim to Hermia is all the more evident, as this production highlights more than most the brute power of the state to enforce heterosexual norms. Egeus' deafness to his daughter's arguments is symbolic -and it also has the effect of forcing Hermia (Bethany Jillard) to speak her own sentence, translating her father's furious signs for the onstage audience. The silently watching Hippolyta's (Maev Beaty) uneasy relationship with Theseus (Scott Wentworth) is rendered more obviously tense and coercive; she is attended by armed Amazons, and her surrender seems at best conditional, and tested by this display of patriarchal dominance. This made wonderful sense of her conversation with Theseus on the hunt, as her references to Hercules become intentional goading, a deliberately cruel reference to a demi-god former lover. Wentworth's assurance that his hounds are bred "of the Athenian kind" is an insecure lover offering what he knows is second best.

The ending of the lovers' plot is carefully staged to acknowledge and resolve those tensions. Wentworth performs his reversal of the law as a placatory gift to his future queen, and matched word with gesture, offering each couple a flower, and, tentatively, one to Hippolyta. It is, in effect, another proposal of marriage that he is relieved she accepts.

The other reconciled couple are equally strikingly played. It's a gay wedding, and it wouldn't be a gay wedding without a healthy dose of camp. Filling those shoes - we couldn't tell if they were pumps or slingbacks - on alternate nights are Evan Buliung (Titania at the performance we attended) and Jonathan Goad. Titania is emphatically the fairy queen. She sings falsetto. She dances. She ad-libs lines that reflect the cross-casting of the play and the sexuality the grooms in the frame. In short, she is a one-woman assault on heteronormativity and predictability, occupying in many ways the role usually played by Puck (Chick Reid, somewhat sidelined in this production). At once stately and mischievous, and feminine while deconstructing femininity, Buliung's performance, too, lent urgency and intellectual depth to the production. This is a fairy queen who can be maternal and self-consciously feminine, and then chest-bump her husband. We invite readers who saw Goad - a splendidly butch and sardonic Oberon in the performance we saw - as Titania to send us comments for inclusion in an updated review.

Goad's Oberon is above all the purveyor of magic in the play, and the production walked a fine line between playing the magic for real and acknowledging the theatricality of the event. The lovers in the grip of the love potion responded physically to Oberon's gestures, heads and feet raised off the ground, clearly in the throes of enchantment. But such moments were also played for laughs, as Goad sadistically held Demetrius in that difficult position - clawing for support at Goad's belt - with a gleeful "Nice abs!" Further magical effects were achieved by the liberal use of child labour to whack the lovers with branches, none too gently guiding their steps through the fog of the forest. As the lovers succumbed to exhaustion they were literally weighed 
down by their young cast-mates - Demetrius complaining as he was overcome "I still have lines!"

The presence of the children - perhaps necessarily - meant that the production pulled some of its punches. When Titania's guard (played by a child) is overcome by Puck's blow dart, the fainting child was caught by an adult cast member. Similarly, the interlude between Bottom (an oddly subdued Stephen Ouimette) and Titania becomes all innocence - a conceptually questionable decision for a production that otherwise pushes the envelope on gender norms. The opposite effect was achieved by having the Changeling a physical presence, tenderly held by Titania (who covered his ears when speaking of his mother's death), and rather abstractedly won by Oberon. This was a real emotional defeat, even if Titania exits seeming to promise that the subject is not closed.

The presence of child actors also led to occasional breaking of the frame. To have fairies sing Bruno Mars' "Grenade" after Helena has been dismissed by Demetrius might make some sense; to have children sing a song of unrequited love at a wedding is - we would hope - improbable. Another song, too, tested the flexibility of the frame to the breaking point. After Pyramus and Thisbe, interrupted in this staging by an increasingly intoxicated Hippolyta - Bottom leads the cast in a frame-breaking rendition of New Order's "Bizarre Love Triangle." In and of itself, this is no problem. But Wentworth then ends the raucous music as the host at a suburban wedding, warning the guests that "I have neighbours!" This, unfortunately, comes before the fairies' magical blessing of the three - sorry, with the grooms four - marriage beds. Rather than being a commentary on magic bleeding into the mundane, the ending seems confusing and confused.

The newspaper reviews have ranged from the stellar (Nestruck in The Globe and Mail) to the witheringly dismissive (Ouzounian in the Star) and everything in between (Cushman in the Post). For some, it's a matter of taste; pop music intervals in Shakespeare are not everyone's cup of tea. Abraham's staging has a lot going on, and perhaps it's difficult to keep so many plates in the air without breaking one or two. But the diversity that he places front and centre in his conception of the show necessarily means an eclectic mix, and his queer sensibility in approaching the frame means it would be frankly disappointing if some sensibilities were not offended. The aesthetics of queer protest draw on carnivalesque displays of bad taste and "the riot of the tipsy bacchanals" is not out of place in such a context. Abraham's show is here (and now) and queer - get used to it.

Roderick McKeown recently defended his PhD at the University of Toronto. His thesis, "Performative Language and Social Status in Shakespeare," won his university's Clifford Leech Prize for the best doctoral thesis on dramatic literature. The work explores the complex operation of socially situated utterances in making powerful-yet off-record-claims to social status through a more nuanced understanding of the 
interrelationship between performative and "constative" speech. While revising his thesis for publication as monograph, he launched a new project, using early modern letters as historical context to examine the dynamics of extended families in Tudor and Stuart domestic tragedies. His publications include articles on Henry VIII (or All is True), Much Ado About Nothing, and The Three Ladies of London, in addition to theater reviews.

Sarah Star is currently teaching Shakespeare at the University of Toronto, Mississauga and has previously taught Medieval and Early Modern Drama. She recently defended her dissertation, "The Seat of the Soul: Blood and Spirituality in Late Medieval English Literary Culture", at the University of Toronto. Her research argues for a previously unacknowledged intersection among the histories of fourteenth-century literary, medical, and vernacular intellectual culture, showing how medieval texts use a specifically physiological language to represent transformative miracles. These texts also, she argues, do what medicine cannot: they complicate and extend their physiological background in order to represent religious identities, mark religious difference, and explain the inextricability of physical and spiritual life. She has published articles on Chaucer and Middle English romance, and has articles forthcoming on the relationship between early English literature and medicine.

\section{Production Details}

\section{General}

Title

Year

Theater Company

Theaters

Start Date

End Date

Cast

Theseus
Hippolyta
PUCK

EGEUS

LYSANDER

DEMETRIUS

HERMIA

HELENA

Philostrate
A Midsummer Night's Dream

2014

Stratford Festival of Canada

Festival Theatre (Canada)

2014-10-11

2014-05-31

\author{
SCOTT WENTWORTH \\ MAEV BEATY \\ CHICK REID \\ Michael SPENCER-DaVis \\ TARA ROSLING \\ MiKe SHARA \\ BETHANY JILLARD \\ LIISA REPO-MARTELL \\ Michael Blake
}




\begin{tabular}{|c|c|}
\hline Воттом & STEPHEN OUIMETTE \\
\hline QUINCE & LALLY CADEAU \\
\hline SNUG & KARL ANG \\
\hline FLUTE & VICTOR ERTMANIS \\
\hline SNOUT & KeITH Dinicol \\
\hline STARVELING & BRAD HODDER \\
\hline PEASEBLOSSOM & HAZEL MARTELL-ABRAHAM \\
\hline COBWEB & GRACI LEAHY \\
\hline MustardseEd & BROOKLYN RICKERT \\
\hline ChANGELING CHILD & CHARLIE Rose NeIS \\
\hline SECOND FAIRY & SAVITA BRICKMAN-MAXWELL \\
\hline FIRST FAIRY & Josh BUCHWALD \\
\hline Titania/Oberon & EVAN BULIUNG \\
\hline MOTE & ISABELLA CASTILLO \\
\hline TITANIA/OBERON & JONATHAN GOAD \\
\hline WEDDING COUPLE & Josue Laboucane, Thomas Olajide \\
\hline SENTINEL & GABRIEL LONG \\
\hline ATTENDANT TO EgEUS & DEREK MORAN \\
\hline MUSICIAN & THOMAS RYDER PAYNe \\
\hline
\end{tabular}

\section{Creatives}

DIRECTOR

Creative Planning Director

TECHNICAL DiRECTOR

PRODUCER

DRAMATURGE

DESIGNER

CAsting Director

COMPOSER AND SOUND DESIGNER

TAP CHOREOGRAPHY

MOVEMENT DiRECTOR

FIgHT CAPTAIN

Fight DiRECTOR

Stage Manager

Production Stage Managers

Production Stage Managers

Lighting DESIgNER
CHRISTOPHER ABRAHAM

JASON MILLER

JEFF SCOLLON

DAVID AUSTER

TOBY MALONE

JULIE FOX

Beth RusSELL

Thomas Ryder Payne

CARLA BENNETT

SHONA MORRIS

JONATHAN GOAD

JOHN STEAD

MEghan CaLlan

MARgaret PALMER

CYNTHIA TOUSHAN

Michael Walton 